\title{
PERSEPSI MASYARAKAT TERHADAP PENGGUNAAN LAHAN SAWAH DI DESA TOUNELET SATU KECAMATAN SONDER
}

\author{
Lovi Cherry Valentine Katuuk \\ Vicky R. B. Moniaga \\ Juliana R. Mandei
}

\begin{abstract}
This study aims to determine the Perceptions of the Community Against Rice Land Use In Tounelet Village One, Sub-district Sonder. This research was conducted from November 2017 until January 2018, starting from preparation until preparation of research report. The research site is Tounelet Village One, Sub-district Sonder. This research uses primary data and secondary data. Primary data was obtained from 30 respondents by using questionnaire, while secondary data was obtained from print media and online media and from journals in the literature related to this research. Sampling method in this research using purposive sampling method. Result of research indicate that public perception toward Wetland Field Estate is good with perception index $77.27 \%$. The community agrees with the use of existing paddy fields in Tounelet One village, Pigs help both as rice fields and as pig farms.
\end{abstract}

Keywords: Public Perception, Wetland Use, One Tounelet Village, Sonder Sub-district, Minahasa Regency.

\begin{abstract}
ABSTRAK
Penelitian ini bertujuan untuk mengetahui Persepsi Masyarakat Terhadap Penggunaan Lahan Sawah Di Desa Tounelet Satu Kecamatan Sonder. Penelitian ini dilaksanakan sejak bulan November 2017 sampai dengan bulan Januari tahun 2018, mulai dari persiapan sampai penyusunan laporan penelitian. Tempat penelitian adalah Desa Tounelet Satu Kecamatan Sonder. Penelitian ini menggunakan data primer dan data sekunder. Data primer diperoleh dari 30 responden dengan menggunakan kuisioner, sedangkan data sekunder diperoleh dari media cetak dan media online serta dari jurnal-jurnal dn literatur yang berkaitan dengan penelitian ini. Metode pengambilan sampel dalam penelitian ini menggunakan metode purposive sampling. Hasil Penelitian menunjukkan bahwa persepsi masyarakat terhadap Penggunaan Lahan Sawah tergolong baik dengan indeks persepsi 77.27\%. Masyarakat setuju dengan Penggunaan Lahan Sawah yang ada di Desa Tounelet Satu, Ternak Babi membantu baik sebagai lahan sawah maupun sebagai lahan usaha ternak babi.
\end{abstract}

Kata kunci: persepsi masyarakat, penggunaan lahan sawah, Desa Tounelet Satu Kecamatan Sonder, Kabupaten Minahasa. 


\section{PENDAHULUAN}

\section{Latar Belakang}

Persepsi adalah pengamatan tentang objek-objek, peristiwa atau hubungan-hubungan yang diperoleh dengan menyimpulkan informasi dan menafsirkan pesan, memberikan makna pada stimulasi indrawi. Persepsi juga merupakan proses seseorang mengetahui beberapa hal melalui pancaindranya. Istilah persepsi merupakan istilah dari bahasa inggris yakni dari kata perception yang berarti penglihatan, keyakinan dapat melihat atau mengerti. Persepsi merupakan salah satu aspek psikologis yang penting bagi manusia dalam merespon kehadiran berbagai aspek dan gejala di sekitarnya (Mutchar, 2007).

Penggunaan Lahan merupakan aktivitas manusia pada dan dalam kaitannya dengan lahan, yang biasanya tidak secara langsung tampak dari citra. Penggunaan lahan telah dikaji dari beberapa sudut pandang yang berlainan, sehingga tidak ada satu definisi yang benarbenar tepat di dalam keseluruhan konteks yang berbeda. Hal ini mungkin, misalnya melihat penggunaan lahan dari sudut pandang kemampuan lahan dengan jalan mengevaluasi lahan dalam hubungannya dengan bermacammacam karakteristik alami yang disebutkan diatas. Penggunaan lahan berkaitan dengan kegiatan manusia pada bidang lahan tertentu, misalnya permukiman, perkotaan dan persawahan.

Penggunaan lahan juga merupakan pemanfaatan lahan dan lingkungan alam untuk memenuhi kebutuhan manusia dalam penyelenggaraan kehidupannya. Pengertian penggunaan lahan biasanya digunakan untuk mengacu pemanfaatan masa kini. Oleh karena aktivitas manusia di bumi bersifat dinamis, maka perhatian sering ditujukan pada perubahan penggunaan lahan baik secara kualitatif maupun kuantitatif. Pengunaan Lahan Sawah sebenarnya bukan masalah baru. Sejalan dengan adanya peningkatan jumlah penduduk serta meningkatnya kebutuhan infrastruktur seperti, perumahan, jalan, industri, perkantoran, dan bangunan lain menyebabkan kebutuhan akan lahan meningkat. Selain itu, pertumbuhan ekonomi yang tinggi menyebabkan pertumbuhan yang sangat cepat di beberapa sektor ekonomi (Djaenuddin ,2006)

Lahan pertanian dalam penanaman padi mempunyai kendala penurunan produktifitas tanaman padi yaitu kepadatan penduduk, sumber daya manusia, cuaca dan hama, akses distribusi. Utomo (1999), menyatakaan bahwa ialah sebagai modal alami yang melandasi kegiatan kehidupan dan penghidupan. Kepadatan penduduk menyebabkan berkurangnya lahan pertanian sawah karena beralih fungi menjadi bangunan rumah sakit, gedung, jalan raya, pabrik dan pemukiman warga. Sumber daya manusia seperti kurangnya kemampuan membaca peluang, etos kerja rendah, kurangnya penerapan teknologi pertanian. cuaca dan hama seperti kekeringan dan kebanjiran, terserang hama tanaman padi. akses distribusi misalnya lahan sawah jauh dari pusat kota dan akses jalan kurang baik.

Multifungsi pertanian adalah manfaat dari pertanian diluar fungsinya sebagai penghasil barang (produk pertanian). Yang termasuk didalam Multifungsi pertanian adalah fungsi lingkungan, fungsi ekonomi, fungsi ketahanan pangan, fungsi sosial, fungsi budaya dan lain-lain. Manfaat dari lahan multifungsi yaitu, lahan yang sedikit dapat menghasilkan produk yang bervariasi, menjaga kestabilan pendapatan petani, jika satu produk gagal panen masih terdapat produk yang lain jadi petani tidak sampai gulung tikar, mengangkat gizi keluarga, memanfaatkan limbah dan mengangkat kesejahtraan para pengusaha pertanian.

Masyarakat Tounelet Satu menjadikan Multifungsi lahan persawahan padi dan peternakan babi, hal ini diharapkan petani mendapat keuntungan dan penghasilan yang lebih. Disektor persawahan dulunya pupuk dibeli dan mahal harganya sekarang bahanbahan untuk pembuatan pupuk organik mudah diperoleh dan murah tidak memerlukan biaya angkutan. Dengan pupuk kandang ternak babi dapat dimanfatkan untuk padi kerena padi mengambil makanan dari dalam tanah dan tanah yang baik adalah tanah yang mengandung banyak unsur hara. Disektor peternakan babi 
harganya yang tinggi di pasaran dan cara perawatan ternak yang lebih mudah dengan keuntungan besar menjadikan multifungsi lahan sawah padi dan beternak babi dapat lebih maksimal dalam pertanian Desa Tounelet Satu karena petani yang bijak adalah petani yang bisa memanfaatkan semua lahan dengan maksimal. Masayarakat Desa Tounelet Satu memaksimalkan penggunaan lahan pertanian secara khusus di sawah dengan usaha penanaman padi dan sebagian lahan digunakan untuk peternakan babi.

Dari uraian diatas maka penulis tertarik untuk melakukan suatu penelitian dengan judul Persepsi Masyarakat Terhadap Penggunaan Lahan Sawah Di Desa Tounelet Satu Kecamatan Sonder.

\section{Rumusan Masalah}

Berdasarkan latar belakang, maka yang menjadi permasalahan dalam penelitian ini adalah bagaimana persepsi masyarakat terhadap penggunaan lahan sawah di Desa Tounelet Satu Kecamatan Sonder.

\section{Tujuan Penelitian}

Berdasarkan perumusan masalah tersebut, maka tujuan penelitian ini adalah untuk mendeskripsikan persepsi masyarakat terhadap penggunaan lahan sawah.

\section{Manfaat Penelitian}

Hasil penelitian ini diharapkan dapat menjadi sumbangan pengetahuan bagi pemerintah dan masyarakat sebagai bahan pertimbangan dalam mengambil keputusan untuk pengunaan lahan sawah di Desa Tounelet Satu Kecamatan Sonder.

\section{METODOLOGI PENELITIAN}

\section{Tempat dan Waktu Penelitian}

Penelitian ini dilaksanakan di Desa Tounelet Satu, Kecamatan Sonder, Kabupaten Minahasa, selama 9 bulan mulai dari bulan April 2017 sampai bulan Januari 2018 yaitu dari persiapan, pengambilan data sampai pada penyusunan laporan hasil penelitian.

\section{Metode Pengumpulan Data}

Metode pengumpulan data dilakukan dengan menggunakan data primer dan data sekunder. Data primer diperoleh dari wawancara langsung dengan responden dan menggunakan kuisioner yang telah disiapkan. Data sekunder yang diperoleh dari kantor kepala Desa Tounelet Satu Kecamatan Sonder dan instansi yang terkait dan berhubungan dengan penelitian ini serta dari berbagai literatur.

\section{Metode Pengambilan Sampel}

Metode pengambilan sampel dalam penelitian ini adalah metode Simple Random Sampling (Pengambilan sampel secara acak sederhana), dimana Penelitian dilakukan terhadap 30 petani yang memiliki lahan pertanian sawah di Desa Tounelet Satu. Adapun responden dibagi menjadi tiga bagian yaitu 10 responden dari petani padi dan 10 responden dari peternak babi dan 10 dari masyarakat setempat.

\section{Konsep Pengukuran Variabel}

Variabel-variabel yang dikaji dalam penelitian ini adalah:

1. Karakteristik Responden, mencakup

1) Umur, yaitu umur pemilik lahan yang dinyatakan dalam tahun.

2) Tingkat Pendidikan, dilihat dari pendidikan terakhir yang ditempuh responden diukur dalam tahun.

2. Persepsi masyarakat terhadap penggunaan lahan sawah, mencakup

1) Pengunaan lahan sawah untuk tanaman Padi.

2) Pengunaan lahan sawah untuk peternakan Babi.

3) Digunakan untuk tanaman Padi dan Beternak Babi.

3. Persepsi Masyarakat tentang aspek Ekonomi keluarga, mencakup

1) Penggunaan lahan sawah untuk tanaman Padi meningkatkan kebutuhan ekonomi keluarga. 
2) Penggunaan lahan sawah untuk beternak Babi menigkatkan kebutuhan ekonomi keluarga.

3) Penggunaan lahan sawah untuk kedua usaha tersebut meningkatkan kebutuhan ekonomi keluarga.

4. Persepsi masyarakat terhadap aspek kesehatan lingkungan hidup penduduk, mencakup

1) Penggunaan lahan sawah untuk tanaman Padi baik/cocok untuk kesehatan lingkungan hidup.

2) Penggunaan lahan sawah untuk beternak Babi baik/cocok untuk kesehatan lingkungan hidup.

3) Pengunaan lahan sawah untuk kedua usaha tersebut baik/cocok untuk kesehatan lingkungan hidup.

5. Persepsi masyarakat terhadap aspek kemampuan lahan dan kecocokannya, mencakup

1) Persepsi masyarakat terhadap aspek kemampuan lahan dan kecocokannya untuk tanaman Padi.

2) Persepsi masyarakat terhadap aspek kemampuan lahan dan kecocokannya untuk beternak Babi.

3) Persepsi masyarakat terhadap aspek kemampuan lahan dan kecocokannya untuk tanaman Padi dan beternak Babi.

\section{Analisis Data}

Penelitian ini menggunakan metode analisis data, yaitu metode analisis kualitatif deskriptif. Metode analisis deskriptif adalah metode penelitian yang melibatkan analisis data berupa deskriptif dan data tersebut tidak secara langsung dapat dikuantifikasi. Analisis deskriptif merupakan metode pencarian fakta dengan interpretasi yang tepat mengenai masalah-masalah yang ada dalam masyarakat, tata cara yang berlaku, serta situasi-situasi tertentu termasuk tentang hubungan, kegiatan, pandangan, serta proses yang sedang berlangsung dan pengaruh dari suatu fenomena. Dengan menggunakan analisis deskriptif yaitu agar bisa mendeskripsikan persepsi masyarakat terhadap penggunaan lahan sawah untuk penanaman tanaman padi, dan penggunaan untuk peternakan babi. Persepsi adalah persepsi sebagai proses seseorang menjadi sadar akan segala sesuatu dalam lingkungannya melalui indra-indra yang dimilikinya (Yusuf, 2007).

Skala likert digunakan untuk mengukur sikap, pendapat, dan persepsi seseorang atau sekelompok orang tentang fenomena sosial. Dalam penelitian, fenomena social ini telah ditetapkan secara spesifik oleh peneliti, yang selanjutnya disebut sebagai variabel penelitian. (Sugiono, 2009). Begitu juga dengan Anwar (2001), pengukuran persepsi dapat dilakukan dengan menggunakan Skala Likert, dengan kategori sebagai berikut :
1. Sangat Setuju
$:$ SS
2. Setuju
: $\mathrm{S}$
3. Ragu-ragu
$: \mathrm{R}$
4. Tidak Setuju
: TS
5. Sangat Tidak Setuju
: STS

Kriteria pengukuran persepsi yakni :
a. Sangat setuju
Nilai/skor : 5
b. Setuju
Nilai/skor : 4
c. Ragu-ragu
Nilai/skor : 3
d. Tidak setuju
Nilai/skor : 2
e. Sangat tidak setuju Nilai/skor: 1

Cara perhitungan skor keseluruhan untuk mengetahui sikap :

Jumlah Skor Seluruh Kriterium = Capaian Jumlah Skor x Jumlah Responden x Jumlah Instrument pernyataan

Untuk :

$\mathrm{S}_{5}=5 \times 30 \times 12=1.800$

$\mathrm{S}_{4}=4 \times 30 \times 12=1.440$

$\mathrm{S}_{3}=3 \times 30 \times 12=1.080$

$\mathrm{S}_{2}=2 \times 30 \times 12=720$

$S_{1}=1 \times 30 \times 12=360$

Jumlah skor ideal untuk keseluruhan pernyataan $=1.800$ (Tertinggi) Jumlah skor terendah $=360$ (Rendah).

Dengan Interpretasi nilai:

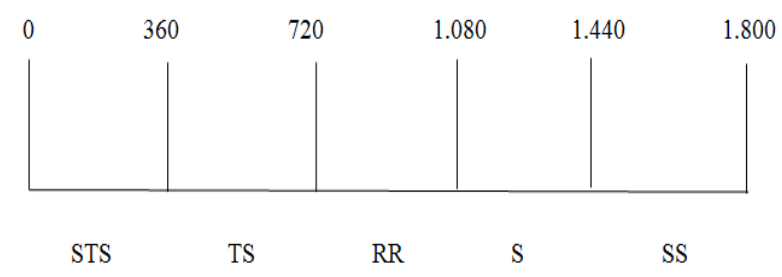


Analisis data yang digunakan merupakan analisis deskriptif yang analisis dengan menggunakan skala pengukuran sikap Likert Scale dimana menurut Ridwan (2010) dalam buku Rumus dan Data dalam Analisis Statistika, adalah sebagai berikut:

Tingkat Sikap $=\frac{\text { JumlahSkorHasilPengumpulanData }}{\text { JumlahSkorIdeal (Tertinggi) }} \times 100 \%$

Dengan Interpretasi nilai:

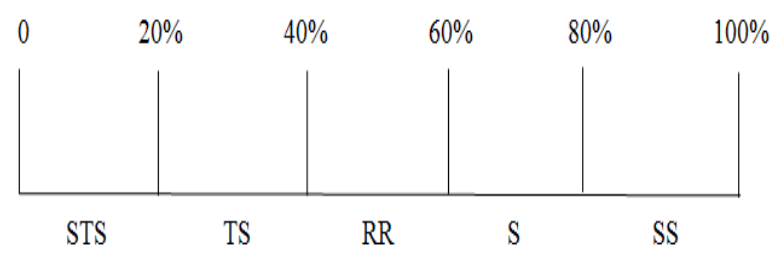

Angka 0\%-20\% = Sangat Tidak Setuju

Angka 21\%-40\% = Tidak Setuju

Angka $41 \%-60 \%=$ Ragu - Ragu

Angka $61 \%-80 \%=$ Setuju

Angka $81 \%-100 \%$ = Sangat Setuju

Untuk setiap indikator penilaian yang dilakukan digunakan perhitungan yang sama pula dengan perhitungan keseluruhan setiap variabelnya yaitu. Dengan mengalikan jumlah skor dengan jumlah responden dan jumlah pertanyaan.

$$
\begin{array}{ll}
\text { SS } & =5 \times 30 \times 1=150 \\
\text { S } & =4 \times 30 \times 1=120 \\
\text { RR } & =3 \times 30 \times 1=90 \\
\text { TS } & =2 \times 30 \times 1=60 \\
\text { STS } & =1 \times 30 \times 1=30
\end{array}
$$

Dengan interval kelas:

$$
\begin{array}{ll}
\text { SS } & : 121-150 \\
\text { S } & : 91-120 \\
\text { RR } & : 61-90 \\
\text { TS } & : 31-60 \\
\text { STS } & : 0-30
\end{array}
$$

\section{HASIL DAN PEMBAHASAN}

\section{Gambaran Umum Lokasi Penelitian}

Desa Tounelet Satu adalah sebuah desa yang terletak di wilayah Kecamatan Sonder, Kabupaten Minahasa, Provinsi Sulawesi Utara. Yang mempunyai luas wilayah $180 \mathrm{Ha}$ dengan jumlah jaga yaitu 4 (empat). Desa Tounelet Satu berbatasan dengan:
- Sebelah Utara berbatasan dengan Desa Rambunan

- Sebelah Timur berbatasan dengan Desa Tounelet Induk

- Sebelah Barat berbatasan dengan Desa Talikuran

- Sebelah Selatan Berbatasan dengan Desa Sendangan dan Kauneran

Jumlah Kepala Keluarga Desa Tounelet Satu yaitu 251 KK dengan jumlah jiwa 822 Jiwa, Laki laki sebanyak 414 jiwa dan Perempuan 408 jiwa.

\section{Karakteristik Responden}

\section{Karakteristik Responden Menurut Tingkat Umur}

Tingkat umur responden bervariasi, mulai dari responden yang berumur 30-an tahun Sampai 70-an tahun. Hal ini dikarenakan tidak ditentukan mengenai tingkat umur dalam penentuan responden. Pengelompokkan umur responden dilakukan dalam upaya mempermudah proses pengolahan data. Kelompok umur dibagi menjadi 4 kelompok umur yaitu 30 - 40 tahun, 41 - 50 tahun, 51 60 tahun, 61 - 70 tahun dan 70 tahun ke atas. Gambaran mengenai kelompok umur responden dapat dilihat dalam Tabel 1.

Tabel 1. Karakteristik Responden Menurut Tingkat Umur

\begin{tabular}{llrr}
\hline No. & Umur (Tahun) & $\begin{array}{c}\text { Jumlah } \\
\text { Responden } \\
\text { (Orang) }\end{array}$ & Persentase (\%) \\
\hline 1 & $30-40$ & 7 & 23.34 \\
2 & $41-50$ & 12 & 40 \\
3 & $51-60$ & 9 & 30 \\
4 & $61-70$ & 1 & 3.33 \\
5 & $>70$ & 1 & 3.33 \\
\hline & Jumlah & 30 & 100 \\
\hline Sumber olahan data primer, 2017
\end{tabular}

Sumber olahan data primer, 2017

Tabel 1 menunjukan bahwa umur responden yaitu dari 30 tahun sampai lebih dari 70 tahun. Umur responden pada interval 61 - 70 tahun dan $>70$ tahun memiliki nilai persentase yang sama yaitu $3.33 \%$ masing-masing 1 responden, pada interval umur 41-50 tahun merupakan persentase nilai yang terbanyak atau merupakan umur responden terbanyak dengan persentase $40 \%$ dengan responden sebanyak 12 orang, dan 30\% merupakan persentase yang 
tebanyak kedua yaitu interval 51-60 tahun dengan jumlah responden 9 orang dan persentase terbanyak ketiga yaitu pada interval $30-40$ tahun dengan jumlah responden 7 orang dan persentase $23.34 \%$. Umur responden termasuk dalam kelompok umur tenaga kerja produktif yaitu dari $17-65$ tahun. Dimana usia ini berpengaruh pada setiap kegiatan yang dilakukan dalam usaha dari setiap responden baik Peternak maupun Petani. Karena semakin tua usia seseorang semakin dibatasi aktivitasnya atau mudah lelah. Begitu sebaliknya dengan orang yang usianya masi muda mengoptimalkan setiap usaha untuk mencapai hasil yang lebih besar.

\section{Karakteristik Responden Menurut Tingkat Pendidikan}

Semakin tinggi tingkat pendidikan seseorang semakin banyak pula pengetahuan atau wawasan yang dimiliki, baik itu menciptakan, menerapkaan tekhnologi baru serta inovasiinovasi yang baru. Dari hasil penelitian yang dilakukan, tingkat pendidikan responden yaitu dari SD, SMP, SMA. Hal ini dapat dilihat pada Tabel 2.

Tabel 2. Karakteristik Responden Menurut Tingkat Pendidikan

\begin{tabular}{|c|c|c|c|}
\hline No. & $\begin{array}{l}\text { Tingkat } \\
\text { Pendidikan }\end{array}$ & $\begin{array}{c}\text { Jumlah Responden } \\
\text { (Orang) }\end{array}$ & $\begin{array}{c}\text { Persentase } \\
(\%)\end{array}$ \\
\hline 1 & SD & 4 & 13.33 \\
\hline 2 & SMP & 8 & 26.67 \\
\hline \multirow[t]{2}{*}{3} & SMA & 18 & 60 \\
\hline & Jumlah & 30 & 100 \\
\hline
\end{tabular}

Sumber olahan data primer, 2017

Dari hasil penelitian pada Tabel 1 . perolehan persentase dari masing-masing tingkat pendidikan yaitu, SMA $60 \%$ atau dengan jumlah responden 18 orang dan merupakan persentase responden terbanyak, dan persentase responden yang terkecil yaitu pada tingkat pendidikan SD sebesar $13.33 \%$ atau dengan jumlah responden 4 orang dan jumlah responden pada tingkat SMP $26.67 \%$ dengan jumlah responden 8 orang. Hal ini menunjukan bahwa dalam penentuan responden tidak ditentukan tingkat pendidikannya dan juga menunjukan bahwa siapa saja bisa mengolah suatu lahan yang tidur sebagai lahan aktif dijadikan mata pencaharian baik digunakan sebagai lahan pertanian maupun peternakan tanpa melihat latar belakang pendidikan.

\section{Persepsi Masyarkat Terhadap Penggunaan Lahan Sawah}

Persepsi Masyarakat Terhadap Penggunaan Lahan Sawah Untuk Tanaman Padi

Hasil penelitian dari penilaian pada responden mengenai persepsi terhadap penggunaan lahan sawah untuk tanaman Padi dapat dilihat pada Tabel 3.

\begin{tabular}{|c|c|c|c|c|c|}
\hline No & Kriteria & Skor & Responden & $\begin{array}{l}\text { Total } \\
\text { Skor }\end{array}$ & $\begin{array}{c}\text { Persentase } \\
(\%)\end{array}$ \\
\hline 1 & $\begin{array}{l}\text { Sangat } \\
\text { setuju }\end{array}$ & 5 & 7 & 35 & 33.01 \\
\hline 2 & Setuju & 4 & 11 & 44 & 41.51 \\
\hline 3 & Ragu ragu & 3 & 3 & 9 & 8.5 \\
\hline 4 & $\begin{array}{l}\text { Tidak } \\
\text { setuju }\end{array}$ & 2 & 9 & 18 & 16.98 \\
\hline 5 & $\begin{array}{l}\text { Sangat } \\
\text { tidak } \\
\text { setuju }\end{array}$ & 1 & 0 & 0 & 0 \\
\hline & Jumlah & & 30 & 106 & 100 \\
\hline
\end{tabular}

Sumber olahan data primer, 2017

Tabel 3 menunjukan bahwa persentase penilaian pada kriteria sangat setuju yaitu $33.01 \%$ dengan jumlah skor penilaian yaitu 35. Masyarakat mengatakan sangat setuju dengan penggunaan lahan sawah digunakan untuk menanam Padi karena sejak dulu lahan sudah digunakan untuk lahan pertanian. Pada kriteria setuju persentase penilaian $41.51 \%$ dengan skor penilaian 44. Masyarakat setuju apabila penggunaan lahan sawah sebagai lahan pertanian khususnya ditanami tanaman Padi karena daripada dibiarkan sebagai lahan tidur lebih baik digunakan sebagai mata pencaharian apalagi masyarakat masih banyak yang berprofesi sebagai petani. Persentase penilaian pada kriteria ragu-ragu $8.5 \%$ dengan skor 9. Masyarakat ragu-ragu penggunaan lahan sawah digunakan untuk menanam Padi karena cuaca yang tidak menentu dapat mengakibatkan gagal panen. Persentase penilain pada kriteria tidak setuju $16.98 \%$ dengan skor 18. Masyarakat tidak setuju apabila penggunaan lahan sawah sebagai lahan pertanian khususnya ditanami tanaman Padi karena keuntungannya sedikit. 


\section{Persepsi Masyarakat Terhadap Penggunaan Lahan Sawah Untuk Peternakan Babi}

Hasil penelitian pada indikator persepsi masyarakat terhadap penggunaan lahan sawah untuk peternakan Babi dapat dilihat dalam Tabel 4. Dimana Tabel 4 menjelaskan bahwa persentase penilaian pada kriteria sangat setuju $57.01 \%$ dengan skor 65. Masyarakat sangat setuju apabila lahan sawah digunakan sebagai lahan peternakan Babi. Karena harus dilakukan inovasi terhadap penggunaan lahan sawah, dulunya lahan sawah hanya digunakan sebagai lahan pertanian tapi saat ini lahan sawah juga digunakan sebagai tempat peternakan Babi. Pada kriteria setuju skor yang diperoleh 28 dan persentase $24.56 \%$. Masyarakat setuju apabila lahan sawah digunakan sebagai lahan peternakan Babi karena lebih menguntungkan. Pada kriteria ragu-ragu dengan skor 3 dan perentase $2.63 \%$. Masyarakat ragu-ragu apabila lahan sawah digunakan sebagai lahan peternakan Babi karena belum ada keahlian khusus dalam beternak. Pada kriteria tidak setuju jumlah perolehan skor 18 dan persentase $15.8 \%$. Masyarakat tidak setuju apabila lahan sawah digunakan sebagai lahan peternakan Babi karena dapat mencemari lingkungan.

\begin{tabular}{|c|c|c|c|c|c|}
\hline Tabel & 4. & $\begin{array}{l}\text { epsi } \\
\text { n Saw }\end{array}$ & $\begin{array}{l}\text { yarakat T } \\
\text { untuk Pet }\end{array}$ & $\begin{array}{l}\text { adap } \\
\text { akan } \mathrm{E}\end{array}$ & $\begin{array}{l}\text { Penggunaan } \\
\text { bi }\end{array}$ \\
\hline No & Kriteria & Skor & Responden & $\begin{array}{l}\text { Total } \\
\text { Skor }\end{array}$ & $\begin{array}{l}\text { Persentase } \\
(\%)\end{array}$ \\
\hline 1 & $\begin{array}{l}\text { Sangat } \\
\text { setuju }\end{array}$ & 5 & 13 & 65 & 57.01 \\
\hline 2 & Setuju & 4 & 7 & 28 & 24.56 \\
\hline 3 & $\begin{array}{l}\text { Ragu } \\
\text { ragu }\end{array}$ & 3 & 1 & 3 & 2.63 \\
\hline 4 & $\begin{array}{l}\text { Tidak } \\
\text { setuju }\end{array}$ & 2 & 9 & 18 & 15.8 \\
\hline 5 & $\begin{array}{l}\text { Sangat } \\
\text { tidak } \\
\text { setuju }\end{array}$ & 1 & 0 & 0 & 0 \\
\hline & Jumlah & & 30 & 114 & 100 \\
\hline
\end{tabular}

\section{Persepsi Masyarakat Terhadap Penggunaan Lahan Sawah Untuk Tanaman Padi dan Peternakan Babi}

Hasil penelitian pada indikator persepesi masyarakat terhadap penggunaan lahan sawah untuk tanaman Padi dan peternakan Babi dapat dilihat dalam Tabel 5.
Tabel 5. Persepsi Masyarakat Terhadap Penggunaan Lahan

\begin{tabular}{|c|c|c|c|c|c|}
\hline No & Kriteria & Skor & Responden & $\begin{array}{l}\text { Total } \\
\text { Skor }\end{array}$ & $\begin{array}{c}\text { Persentase } \\
(\%)\end{array}$ \\
\hline 1 & $\begin{array}{l}\text { Sangat } \\
\text { setuju }\end{array}$ & 5 & 2 & 10 & 10 \\
\hline 2 & Setuju & 4 & 18 & 72 & 72 \\
\hline 3 & $\begin{array}{l}\text { Ragu } \\
\text { ragu }\end{array}$ & 3 & 0 & 0 & 0 \\
\hline 4 & $\begin{array}{l}\text { Tidak } \\
\text { setuju }\end{array}$ & 2 & 10 & 18 & 18 \\
\hline 5 & $\begin{array}{l}\text { Sangat } \\
\text { tidak } \\
\text { setuju }\end{array}$ & 1 & 0 & 0 & 0 \\
\hline & Jumlah & & 30 & 100 & 100 \\
\hline
\end{tabular}

Tabel 5 menunjukan persentase penilaian pada kriteria sangat setuju yaitu $10 \%$ dengan skor 10. Masyarakat sangat setuju apabila lahan sawah digunakan sebagai lahan untuk tanaman Padi dan ternak Babi karena kedua usaha tersebut sudah ditekuni sejak lama. Pada kriteria setuju perolehan persentase $72 \%$ dengan skor 72. Masyarakat setuju apabila lahan sawah digunakan sebagai lahan pertanian yang ditanami Padi dan sebagai lahan peternakan yaitu ternak Babi karena kedua usaha tersebut menambah pundi-pundi penghasilan. Pada kriteria tidak setuju jumlah perolehan skor 18 dan persentase $18 \%$. Masyarakat tidak setuju apabila lahan sawah digunakan sebagai lahan untuk tanaman padi dan peternakan Babi karena sebagian masyarakat hanya memiliki keahlian dalam satu bidang saja.

\section{Persepsi Masyarakat Terhadap Penggunaan Lahan Sawah Untuk Tanaman Padi Meningkatkan Kebutuhan Ekonomi Keluarga}

Tabel 6 menyatakan bahwa persentase penilaian pada kriteria sangat setuju $31.25 \%$ dengan skor 40. Masyarakat sangat setuju penggunaan lahan sawah untuk tanaman Padi meningkatkan kebutuhan ekonomi keluarga karena memberikan kontribusi dalam peningkatan ekonomi keluarga. Pada kriteria setuju perolehan skor 88 dan persentase $68.75 \%$. Masyarakat menyatakan setuju karena meskipun tidak sebesar dengan perputaran ternak Babi tapi tetap memenuhi kebutuhan ekonomi keluarga. Hasil dari penelitian pada indikator ini dapat dilihat dalam Tabel 6. 
Tabel 6. Persepsi Masyarakat Terhadap Penggunaan Lahan Sawah untuk Tanaman Padi Meningkatkan Kebutuhan Ekonomi Keluaraga.

\begin{tabular}{|c|c|c|c|c|c|}
\hline No & Kriteria & Skor & Responden & $\begin{array}{l}\text { Total } \\
\text { Skor }\end{array}$ & $\begin{array}{c}\text { Persentase } \\
(\%)\end{array}$ \\
\hline 1 & $\begin{array}{l}\text { Sangat } \\
\text { setuju }\end{array}$ & 5 & 8 & 40 & 31.25 \\
\hline 2 & Setuju & 4 & 22 & 88 & 68.75 \\
\hline 3 & Ragu ragu & 3 & 0 & 0 & 0 \\
\hline 4 & $\begin{array}{l}\text { Tidak } \\
\text { setuju }\end{array}$ & 2 & 0 & 0 & 0 \\
\hline 5 & $\begin{array}{l}\text { Sangat } \\
\text { tidak } \\
\text { setuju }\end{array}$ & 1 & 0 & 0 & 0 \\
\hline & Jumlah & & 30 & 128 & 100 \\
\hline
\end{tabular}

Sumber olahan data primer, 2017

Persepsi Masyarakat Terhadap Penggunaan Lahan Sawah Untuk Ternak Babi Meningkatkan Kebutuhan Ekonomi Keluarga

Hasil dari penelitian pada indikator ini dapat dilihat dalam Tabel 7.

Tabel 7. Persepsi Masyarakat Terhadap Penggunaan Lahan Sawah untuk Peternakan Babi Meningkatkan Kebutuhan Ekonomi Keluaraga.

\begin{tabular}{rlrrrr}
\hline No & Kriteria & Skor & Responden & $\begin{array}{c}\text { Total } \\
\text { Skor }\end{array}$ & $\begin{array}{c}\text { Persentase } \\
(\%)\end{array}$ \\
\hline 1 & Sangat & 5 & 6 & 30 & 23.81 \\
& setuju & & & & \\
2 & Setuju & 4 & 24 & 96 & 76.19 \\
3 & Ragu ragu & 3 & 0 & 0 & 0 \\
4 & Tidak & 2 & 0 & 0 & 0 \\
& setuju & & & & 0 \\
5 & Sangat & 1 & 0 & 0 & \\
& tidak & & & & \\
& setuju & & & & \\
\hline & Jumlah & & 30 & & \\
\hline
\end{tabular}

Sumber olahan data primer, 2017

Tabel 7 menyatakan bahwa persentase penilaian pada kriteria sangat setuju $23.81 \%$ dengan skor 30. Karena memberikan kontribusi dalam peningkatan ekonomi keluarga. Pada kriteria setuju perolehan skor 96 dan persentase penilaian $76.19 \%$. Karena perputaran usaha ternak Babi lebih besar dibandingkan tanaman Padi dan dari hasil ternak babi menunjang kebutuhan ekonomi keluarga sehingga banyak yang beralih dari usaha tanaman Padi ke ternak Babi.

Persepsi Masyarakat Terhadap Penggunaan Lahan Sawah Untuk Tanaman Padi dan Ternak Babi Meningkatkan Kebutuhan Ekonomi Keluarga

Hasil penilaian pada indikator ini dapat dilihat dalam Tabel 8.
Tabel 8. Persepsi Masyarakat Terhadap Penggunaan Lahan Sawah untuk Tanaman Padi dan Peternakan Babi Meningkatkan Kebutuhan Ekonomi Keluraga.

\begin{tabular}{|c|c|c|c|c|c|}
\hline No & Kriteria & Skor & Responden & $\begin{array}{l}\text { Total } \\
\text { Skor }\end{array}$ & $\begin{array}{c}\text { Persentase } \\
(\%)\end{array}$ \\
\hline 1 & $\begin{array}{l}\text { Sangat } \\
\text { setuju }\end{array}$ & 5 & 0 & 0 & 0 \\
\hline 2 & Setuju & 4 & 30 & 120 & 100 \\
\hline 3 & $\begin{array}{l}\text { Ragu } \\
\text { ragu }\end{array}$ & 3 & 0 & 0 & 0 \\
\hline 4 & $\begin{array}{l}\text { Tidak } \\
\text { setuju }\end{array}$ & 2 & 0 & 0 & 0 \\
\hline 5 & $\begin{array}{l}\text { Sangat } \\
\text { tidak } \\
\text { setuju }\end{array}$ & 1 & 0 & 0 & 0 \\
\hline & Jumlah & & 30 & 120 & 100 \\
\hline
\end{tabular}

Sumber olahan data primer, 2017

Tabel 8 menjelaskan bahwa persentase penilaian pada kriteria setuju $100 \%$ dengan skor 120. Artinya penggunaan lahan sawah baik untuk ternak Babi maupun tanaman Padi masing-masing meningkatkan kebutuhan ekonomi keluarga. Hal ini sejalan dengan pernyataan responden bahwa walaupun dengan keuntungan berbeda tapi keduanya menguntungkan dan meningkatkan ekonomi keluarga, bahkan dengan kedua usaha ini masyarakat boleh menyekolahkan anak-anak sampai ke jenjang perguruan tinggi.

\section{Persepsi Masyarakat Tentang Penggunaan Lahan Sawah Terhadap Aspek Lingkungan Hidup Penduduk}

Persepsi Masyarakat Tentang Penggunaan Lahan Sawah untuk Tanaman Padi Terhadap Aspek Lingkungan Hidup Penduduk

Penilaian pada indikator persepsi masyarakat terhadap penggunaan lahan sawah untuk tanaman Padi dapat dilihat dalam Tabel 9. Tabel 9 menjelaskan bahwa persentase penilaian pada kriteria sangat setuju yaitu $55.56 \%$ dengan skor 75. Masyarakat sangat setuju tentang penggunaan lahan sawah untuk tanaman Padi dilihat dari aspek lingkungan baik atau cocok. karena tidak ada pencemaran lingkungan dari usaha tersebut. Pada kriteria setuju persentase penilaian yaitu $44.44 \%$ dengan skor 60 . Responden mengatakan setuju karena masyarakat tidak terganggu dengan aktivitas dengan penggunaan lahan untuk tanaman Padi. 
Tabel 9. Persepsi Masyarakat Terhadap Penggunaan Lahan Sawah untuk Tanaman Padi Terhadap Aspek Kesehatan Lingkungan

\begin{tabular}{rlrrrr}
\hline No & Kriteria & Skor & Responden & $\begin{array}{c}\text { Total } \\
\text { Skor }\end{array}$ & $\begin{array}{c}\text { Persentase } \\
(\%)\end{array}$ \\
\hline 1 & Sangat & 5 & 15 & 75 & 55.56 \\
& setuju & & & & \\
2 & Setuju & 4 & 15 & 60 & 44.44 \\
3 & Ragu ragu & 3 & 0 & 0 & 0 \\
4 & Tidak & 2 & 0 & 0 & 0 \\
& setuju & & & & \\
5 & Sangat & 1 & 0 & 0 & 0 \\
& tidak & & & & \\
& setuju & & 30 & 135 & 100 \\
\hline \multicolumn{2}{l}{ Jumlah } & & &
\end{tabular}

Persepsi Masyarakat Tentang Penggunaan Lahan Sawah Untuk Ternak Babi Terhadap Aspek Lingkungan Hidup Penduduk

Hasil penilaian pada indikator perepsi masyarakat tentang penggunaan lahan sawah untuk ternak Babi dapat dilihat dalam Tabel 10.

Tabel 10. Persepsi Masyarakat Terhadap Penggunaan Lahan Sawah untuk Peternakan Babi Terhadap Aspek Kesehatan Lingkungan

\begin{tabular}{llrrrr}
\hline No & Kriteria & Skor & Responden & $\begin{array}{r}\text { Total } \\
\text { Skor }\end{array}$ & $\begin{array}{c}\text { Persentase } \\
(\%)\end{array}$ \\
\hline 1 & Sangat & 5 & 4 & 20 & 20.83 \\
& setuju & & & & \\
2 & Setuju & 4 & 12 & 48 & 50 \\
3 & Ragu ragu & 3 & 0 & 0 & 0 \\
4 & Tidak & 2 & 14 & 28 & 29.17 \\
& setuju & & & & \\
5 & Sangat & 1 & 0 & 0 & 0 \\
& tidak & & & & \\
& setuju & & & & \\
\hline & Jumlah & & 30 & 96 & 100 \\
\hline
\end{tabular}

Sumber olahan data primer, 2017

Tabel 10 menjelaskan bahwa persentase penilaian pada kriteria sangat setuju yaitu $20.83 \%$ dengan skor 20. Masyarakat sangat setuju dengan penggunaan lahan sawah dilihat dari aspek kesehatan lingkungan baik atau cocok untuk ternak Babi karena sampai saat ii belum ada masyarakat yang komplain dengan usaha ternak Babi. Pada kriteria setuju perolehan skor penilaian 48 dengan persentase $50 \%$. Masyarakat setuju dengan penggunaan lahan sawah dilihat dari aspek kesehatan lingkungan baik atau cocok untuk ternak Babi karena Meskipun bau kotoran ternak terkadang mengganggu penciuman masyarakat tetapi selalu diupayakan kebersihan semaksimal mungkin agar tidak mencemari lingkungan. Pada kriteria tidak setuju perolehan skor yaitu 28 dengan persentase $29.17 \%$ Masyarakat tidak setuju dengan penggunaan lahan sawah dilihat dari aspek kesehatan lingkungan baik atau cocok untuk ternak Babi karean bau kotoran dari ternak Babi terkadang mengganggu penciuman masyarakat.

\section{Persepsi Masyarakat Tentang Penggunaan Lahan Sawah Untuk Tanaman Padi dan Ternak Babi Terhadap Aspek Lingkungan Hidup Penduduk}

Hasil penelitian pada indikator persepsi masyarakat tentang penggunaan lahan sawah untuk tanaman Padi dan ternak Babi terhadap aspek lingkungan hidup penduduk dapat dilihat dalam Tabel 11.

Tabel 11. Persepsi Masyarakat Terhadap Penggunaan Lahan Sawah untuk Tanaman Padi dan Peternakan Babi Terhadap Aspek Kesehatan Lingkungan

\begin{tabular}{|c|c|c|c|c|c|}
\hline No & Kriteria & Skor & Responden & $\begin{array}{l}\text { Total } \\
\text { Skor }\end{array}$ & $\begin{array}{c}\text { Persentase } \\
(\%)\end{array}$ \\
\hline 1 & $\begin{array}{l}\text { Sangat } \\
\text { setuju }\end{array}$ & 5 & 6 & 30 & 29.41 \\
\hline 2 & Setuju & 4 & 12 & 48 & 47.06 \\
\hline 3 & Ragu ragu & 3 & 0 & 0 & 0 \\
\hline 4 & $\begin{array}{l}\text { Tidak } \\
\text { setuju }\end{array}$ & 2 & 12 & 24 & 23.53 \\
\hline 5 & $\begin{array}{l}\text { Sangat } \\
\text { tidak } \\
\text { setuju }\end{array}$ & 1 & 0 & 0 & 0 \\
\hline & Jumlah & & 30 & 102 & 100 \\
\hline
\end{tabular}

Tabel 11 menjelasakan skor penilaian yang diperoleh pada kriteria sangat setuju yaitu 30 dengan persentase $29.41 \%$. Masyarakat sangat setuju karena bau yang disebabkan oleh salah satu usaha dapat diatasi dengan baik. Pada kriteria setuju persentase penilaian yaitu $47.06 \%$ dengan skor 48. Artinya dari aspek kesehatan lingkungan terhadap penggunaan lahan sawah untuk tanaman Padi dan ternak Babi baik atau cocok. walaupun ada bau yang mengganggu penciuman karena kotoran ternak tidak mengganggu aktivitas masyarakat karena sudah terbiasa dengan hal tersebut. Pada kriteria tidak setuju perolehan skor yaitu 24 dengan persentase penilaian $23.53 \%$. masyarakat tidak setuju karena meskipun masyarakat setempat sudah terbiasa dengan bau yang disebabkan oleh salah satu usaha tetapi belum tentu dengan masyarakat yang berkunjung, otomatis mengganggu penciuman dari masyarakat yang berkunjung. 


\section{Persepsi Masyarakat Tentang Penggunaan Lahan Sawah Terhadap Aspek Kemampuan Lahan dan Kecocokannya}

Persepsi Masyarakat Tentang Penggunaan Lahan Sawah Untuk Tanaman Padi Terhadap Aspek Kemampuan Lahan dan Kecocokannya

Hasil penilaian pada indikator persepsi masyarakat tentang penggunaan lahan sawah untuk tanaman Padi terhadap aspek kemampuan lahan dan kecocokannya dapat dilihat dalam Tabel 12.

\begin{tabular}{|c|c|c|c|c|c|c|}
\hline \multirow{2}{*}{$\begin{array}{l}\text { Tabel } \\
\text { No }\end{array}$} & 12. & \multicolumn{5}{|c|}{$\begin{array}{l}\text { Persepsi Masyarakat Terhadap Penggunaan Lahan } \\
\text { Sawah untuk Tanaman Padi Terhadap Aspek } \\
\text { Kemampuan Lahan }\end{array}$} \\
\hline & & iteria & Skor & Responden & $\begin{array}{l}\text { Total } \\
\text { Skor }\end{array}$ & $\begin{array}{c}\text { Persentase } \\
(\%)\end{array}$ \\
\hline 1 & $\begin{array}{l}\text { San } \\
\text { setu }\end{array}$ & & 5 & 5 & 25 & 20 \\
\hline 2 & Setu & & 4 & 25 & 100 & 80 \\
\hline 3 & $\begin{array}{l}\text { Rag } \\
\text { ragu }\end{array}$ & & 3 & 0 & 0 & 0 \\
\hline 4 & $\begin{array}{l}\text { Tid } \\
\text { setu }\end{array}$ & & 2 & 0 & 0 & 0 \\
\hline 5 & $\begin{array}{l}\text { San } \\
\text { tida } \\
\text { setu }\end{array}$ & & 1 & 0 & 0 & 0 \\
\hline & Jum & lah & & 30 & 125 & 100 \\
\hline
\end{tabular}

Sumber olahan data primer, 2017

Tabel 12 menjelaskan bahwa skor penilaian yang diperoleh pada kriteria sangat setuju yaitu 25 dan persentase $20 \%$. Masyarakat sangat setuju memang lahan di daerah tersebut sudah digunakan untuk lahan pertanian. Pada kriteria setuju skor penilaian yang diperoleh yaitu 100 dengan persentase penilaian $80 \%$. Masyarakat setuju karena lahan berpotensi untuk pertanian terlebih untuk tanaman padi dilihat dari ketersediaan air yang melimpah.

Persepsi Masyarakat Tentang Penggunaan Lahan Sawah Untuk Ternak Babi Terhadap Aspek Kemampuan Lahan dan Kecocokannya

Hasil penelitian pada indikator persepsi masyarakat tentang penggunaan lahan sawah untuk ternak Babi terhadap aspek kemampuan lahan dan kecocokannya dapat dilihat dalam Tabel 13.
Tabel 13. Persepsi Masyarakat Terhadap Penggunaan Lahan Sawah untuk Peternakan Babi Terhadap Aspek Kemampuan Lahan

\begin{tabular}{rlrrrr}
\hline No & Kriteria & Skor & Responden & $\begin{array}{c}\text { Total } \\
\text { Skor }\end{array}$ & $\begin{array}{c}\text { Persentase } \\
(\%)\end{array}$ \\
\hline 1 & $\begin{array}{l}\text { Sangat } \\
\text { setuju }\end{array}$ & 5 & 9 & 45 & 42.06 \\
2 & $\begin{array}{l}\text { Setuju } \\
3\end{array}$ & 4 & 10 & 40 & 37.38 \\
4 & $\begin{array}{l}\text { Ragu- } \\
\text { ragu } \\
\text { Tidak } \\
\text { setuju } \\
5\end{array}$ & 3 & 0 & 0 & 0 \\
& $\begin{array}{l}\text { Sangat } \\
\text { tidak } \\
\text { setuju }\end{array}$ & 1 & 11 & 22 & 20.56 \\
& & 0 & 0 & 0 \\
\hline & Jumlah & & 30 & 107 & 100 \\
\hline Sumber
\end{tabular}

Sumber olahan data primer, 2017

Tabel 13 menjelaskan bahwa perolehan persentase penilaian pada kriteria sangat setuju yaitu $42.06 \%$ dengan skor 45 . Masyarakat sangat setuju karena lahan yang dekat dengan kali besar sehingga pembuangan kotoran ternak langsung ke kali besar. Pada kriteria setuju perolehan skor penilaian yaitu 40 dengan persentase $37.38 \%$. masyarakat setuju ternak Babi cocok dilakukan karena ketersediaan air untuk pembersihan sudah tersedia, serta saluran pembuangan kotoran ternak pun sudah tersedia, bahkan kotoran ternak dapat dijadika pupuk organik untuk tanaman Padi. Pada kriteria tidak setuju perolehan skor penilaian yaitu 22 dengan persentase $20.56 \%$. masyarakat tidak setuju karena pembuangan limbah kotoran ternak langsung ke kali besar sehingga mencemari kali tersebut.

Persepsi Masyarakat Tentang Penggunaan Lahan Sawah Untuk Tanaman Padi dan Ternak Babi Terhadap Aspek Kemampuan Lahan dan Kecocokannya

Hasil penelitian pada indikator persepsi masyarakat tentang penggunaan lahan sawah untuk tanaman Padi dan ternak Babi terhadap aspek kemampuan lahan dan kecocokannya dapat dilihat dalam Tabel 14. 
Tabel 14. Persepsi Masyarakat Terhadap Penggunaan Lahan Sawah untuk Tanaman Padi dan Peternakan Babi Terhadap Aspek Kemampuan Lahan

\begin{tabular}{|c|c|c|c|c|c|}
\hline No & Kriteria & Skor & Responden & $\begin{array}{l}\text { Total } \\
\text { Skor }\end{array}$ & $\begin{array}{c}\text { Persentase } \\
(\%)\end{array}$ \\
\hline 1 & $\begin{array}{l}\text { Sangat } \\
\text { setuju }\end{array}$ & 5 & 9 & 45 & 42.06 \\
\hline 2 & Setuju & 4 & 10 & 40 & 37.38 \\
\hline 3 & Ragu ragu & 3 & 0 & 0 & 0 \\
\hline 4 & $\begin{array}{l}\text { Tidak } \\
\text { setuju }\end{array}$ & 2 & 11 & 22 & 20.56 \\
\hline 5 & $\begin{array}{l}\text { Sangat } \\
\text { tidak } \\
\text { setuju }\end{array}$ & 1 & 0 & 0 & 0 \\
\hline & Jumlah & & & 107 & 100 \\
\hline
\end{tabular}

Tabel 14 menjelaskan bahwa perolehan skor penilaian pada kriteria sangat setuju yaitu 60 dengan persentase penilaian $45.5 \%$. masyarakat sangat setuju karena dilihat dari kemampuan lahan untuk usaha tanaman Padi dan ternak Babi sangat cocok atau sesuai. Pada kriteria setuju perolehan skor penilaian yaitu 72 dengan persentase $54.5 \%$. Persepsi masyarakat terhadap penggunaan lahan sawah dilihat dari aspek kemampuan lahan untuk tanaman Padi dan ternak Babi sangatlah cocok atau sesuai untuk pengembangannya. hal ini dilihat dari ketersediaan air yang cukup dan tidak perlu mengeluarkan modal untuk membeli air baik digunakan untuk tanaman Padi maupun untuk ternak Babi dalam membersihkan kandang dari kotoran ternak.

\section{Rekapitulasi hasil dari penelitian Persepsi Masyarakat Terhadap Penggunaan Lahan Sawah di Desa Tounelet Satu Kecamatan Sonder}

Rekapitulasi hasil dari penelitian Persepsi Masyarakat Terhadap Penggunaan Lahan Sawah di Desa Tounelet Satu Kecamatan Sonder dapat dilihat pada tabel 3. Total skor yang diperoleh dari penilaian pada setiap indikator 1.391. Hal ini menggambarkan bahwa persepsi masyarakat berada pada kriteria atau interval setuju dengan interval kelas $1.080-1.440$.

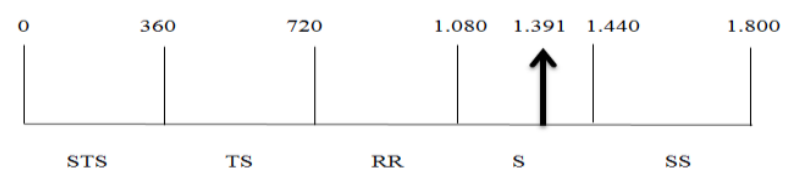

Tingkat Sikap $=\frac{1391}{1800} \times 100 \%=77.27 \%$

Dengan Interpretasi nilai :

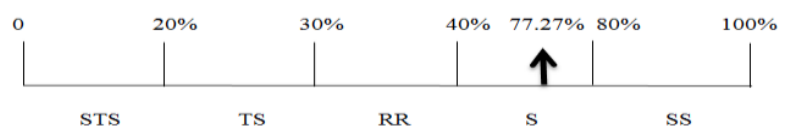

Tingat sikap persepsi masyarakat dengan persentase nilai $77.27 \%$ menggambarkan bahwa masyarakat setuju dengan penggunaan lahan yag digunakan oleh masyarakat di Desa Tounelet Satu Kecamatan Sonder. Jadi Persepsi Masyarakat Terhadap Penggunaan Lahan Di Desa Tounelet Satu Kecamatan Sonder masih tergolong baik. Intinya kesadaran masyarakat untuk menggunakan lahan menjadikan suatu usaha daripada membiarkan lahan tersebut menjadi lahan tidur. Hal ini dibuktikan dengan pernyaatan salah satu responden pada saat wawancara dilapangan. Responden menyatakan bahwa daripada lahan dibiarkan tidur lebih baik digunakan untuk usaha baik digunakan untuk tanaman Padi maupun beternak Babi atau usaha lain yang pastinya memberikan keuntungan atau menambah pendapatan.

\section{KESIMPULAN DAN SARAN}

\section{Kesimpulan}

Berdasarkan hasil penelitian yang dilakukan mengenai Persepsi Masyarakat Terhadap Penggunaan Lahan di Desa Tounelet Satu Kecamatan Sonder dapat disimpulkan bahwa:

- Persepsi masyarakat untuk penggunaan Lahan Sawah $72 \%$ masyarakat setuju untuk melakukan kedua-duanya yakni usaha peternakan Babi dan Penanaman Padi.

- Persepsi masyarakat tentang penggunaan Lahan Sawah terhadap aspek ekonomi Keluarga $100 \%$ setuju untuk melakukan kedua usaha yakni peternakan Babi dan penanaman Padi secara bersamaan

- Persepsi masyarakat tentang penggunaan Lahan Sawah terhadap aspek lingkungan hidup Penduduk sangat setuju 20.83\% kemudian Setuju $50 \%$ dan tidak setuju $29.17 \%$ untuk penggunaan Lahan Sawah sebagai peternakan Babi dan untuk Penanaman Padi 100\% setuju.

- Persepsi masyarakat tentang penggunaan Lahan Sawah terhadap aspek kemampuan lahan, yang tertinggi adalah kemampan lahan untuk tanaman Padi seberar $80 \%$ 


\section{Saran}

Persepsi Masyarakat Terhadap Penggunaan Lahan Di Desa Tounelet Satu Kecamatan Sonder harus dipertahankan dan lebih menyatukan persepsi mengenai penggunaan lahan yang ada.

\section{DAFTAR PUSTAKA}

Adiwilaga, 2011. Ilmu Usahatani. Bandung. Penerbit Alumni.

Anwar, 2001 Manajemen Sumber Daya Manusia Perusahaan, Remaja Rosdakarya, Bandung.

Arsyad, 2002. Media Pembelajaran. Jakarta: Raja Grafindo Persada.

Djaenudin, D., Marwan, H., Subagyo, Hidayat, A., 2006. Technical Guideline of Land Evaluation for Agricultural Commodity. Agency for Soil and Agroclimate, Bogor.

Ilham, 2004. Manajemen Sumberdaya Dan Kinerja Aparatur Pemerintah Daerah. Bandung.

Kotler, 2002. Manajemen Pemasaran. Jakarta: Prenhallindo.

Lestari. 2013. Pengembangan Bahan Ajar Berbasis Kompetensi. Padang: Akademia Permata.

Mutchar T.W. 2007. Studi Komparatif Persepsi Dan Manfaat Siswa SMP Tentang SMK. Skripsi Sarjana Jurusan Pendidikan Teknik Sipil. Bandung.

Nitisusastro. 2013. Perilaku Konsumen dalam perspektif kewirausahaan. Alfabeta: Bandung.

Puspasari, 2012. Faktor - faktor yang Mempengaruhi Alih Fungsi Lahan Pertanian dan Dampaknya Terhadap Pendapatan Petani Institut Pertanian Bogor.
Rachman, M. 2013. Persepsi Masyarakat Terhadap Keberadaan Peternak Babi Kampung Katimbang Kelurahan Paccerakkang Kecamatan Biringkanaya, Makassar. Universitaas Hasanuddin Makassar. Skripsi.

Ridwan. 2010. Rumus dan Data dalam Analisis Statistika. Jakarta: Alfabeta.

Siagian. R, 1999; Pengantar Manajemen Agribisnis, Gadjah Mada.

Simatupang, \& Irawan. 2005, Bermain Sebagai Upaya Dini Menanamkam Aspek Sosial Bagi Siswa Sekolah Dasar, Jurnal Pendidlkan Jasmani Indonesia.

Sitorus 1999. Evaluasi Sumberdaya Lahan. Bandung : Tarsito.

Sofyan. 2007. Teori Akuntansi. Edisi Revisi. Jakarta: Rajawali Pers.

Solomon, Louis. 2013. Ortopedi dan Fraktur Sistem Apley. Jakarta: Widya Medika.

Sugiono. 2009. Metode Penelitian Bisnis, Bandung Alfabeta CV.

Sumaryanto dan Tahlim, 2005. Pemahaman Dampak Negatif Konversi Lahan Sawah Sebagai Landasan Perumusan Strategi Pengendaliannya. Jakarta.

Suparmoko, M. 2008. Ekonomi Publik, Untuk Keuangan dan Pembangunan Daerah. Andi. Yogyakarta.

Utomo, 1992. Pembangunan dan Pengendalian Alih Fungsi Lahan. Universitas Lampung. Bandar Lampung.

Utomo, 1999. Bahan Pakan Dan Formulasi Ransum. Fakultas Peternakan Yogyakarta.

Yusuf. 2007. Karakteristik Yoghurt Susu Nabati Kacang Hijau (Phaseolusradiatus L.). Balai Besar Pengembangan Teknologi Tepat Guna. LIPI. Bandung. Jurnal. 